\title{
Prophylactic role of combined treatment with wheat germ oil and ginseng against radiation injury in male rats
}

\author{
S.M. Abdel Fattah*, Th. M. Fahim* and N.M. El-Fatih** \\ *Drug Radiation Research Dept., **Radiation Biology Dept. National Centre for \\ Radiation Research and Technology (NCRRT).
}

\begin{abstract}
Background: This study was designed to investigate the possible ameliorating effect of combined treatment of rats with wheat germ oil [a rich source of vitamin E, octacosanol, policosanol and the essential fatty acids (linoleic and linolenic)] and the antioxidant properties of panax quinquefolium ginseng on radiation-induced oxidative body damage.

Materials and Methods: Animals received wheat germ oil by gavage at a dose of $80 \mathrm{mg} / \mathrm{kg}$ body wt and panax ginseng was intraperitioneally injected with $100 \mathrm{mg} / \mathrm{kg}$ body wt for 10 successive days pre as well as during irradiation and supplementation was extended during the period of radiation exposure of rats to fractionated doses 8 Gy (4 x2Gy).

Results: Experimental investigations were performed at $7^{\text {th }}$ and $10^{\text {th }}$ days after the last dose of irradiation revealed that whole body $\gamma$-irradiation of rats produced a significant rise in the activities of serum markers for liver damage as aspartate aminotransferase (ASAT), alaninetransaminase (ALAT), ammonia and buytryl cholinestase associated with decrease in the serum content of total protein, albumin $(A)$, golublin $(G)$ and $A / G$ ratio indicating acute hepatotoxicity, at the $7^{\text {th }}$ and $10^{\text {th }}$ days post-irradiation. Also, radiation-induced biochemical disorders manifested by significant elvation in serum creatinine and urea levels. Serum lipid profile as total cholesterol (TC), triglyceride (TG), high density lipoprotein-cholesterol (HDL-C) and low density lipoprotein-cholestrol (LDL-C) levels were significantly higher than normal control rats associated with significant decrease in HDL/LDL ratio. Radiation induced an elevation of lipid peroxidation measured as thiobarbituric acid reactive substance (TARS) in plasma and liver. The rats that received combined treatment with wheat germ oil and panax ginseng supplement showed significantly less severe damage and remarkable improvement in all of the measured parameters when compared to irradiated rats. According to the results obtained it could be concluded that combined treatment with whole germ oil and panax ginseng might be a useful candidate against radiation-induced oxidative stress and metabolic disorders without any toxicity.
\end{abstract}

Key words: $\gamma$-irradiation, wheat germ oil, panax ginseng, liver injury

\section{Introduction:}

Ionizing radiation produces harmful effects on the organisms and due to wide spread use of radiation in diagnosis therapy, industry; so many pharmacological interventions could be most potent strategy to protect or amelioration the deleterious effect of ionizing radiation (Jagetia, 2007). Ionizing radiations induce significant elevation in the physiological and metabolic processes, as well as, disorders in blood biochemical parameters (El-Masry and Saad, 2005) and causing chain reaction of oxidation (Ammar, 2009).

Wheat germ oil is extracted from the germ of the wheat kernel. Wheat germ oil is a valuable source of essential fatty acids, including linolenic, palmitic and oleic, protein, minerals, it is naturally rich in vitamins $\mathrm{A}, \mathrm{D}$ and $\mathrm{E}$, and also, contains vitamins B1, B2, B3,B6, policosanal and 
octacosanols, and dietary fibers, phytochemicals and antioxidant propertiies (Ikmak and Dunford, 2005). Experimental studies demonstrated that wheat germ oil can reduce oxidative stress (Alessandri et al., 2006), improve lipid metabolism (Singh et al., 2006), lowers raised blood sugar and cholesterol levels (Ikmak and Dunford, 2005), useful in building muscle strength and endurance, promotes skin cell formation, improve urinary output, prevent rancidity and lower oxygen depletion Vicky et al., (2004). The germ is the most nutritious portion of the wheat and it makes up about $2.5 \%$ of the weight. During the milling process the germ is separated from the bran and starch (Jensen et al., 2004 and Lui, 2007).

Ginseng has been recognized as the most prized medicine among all herbal medicine. Ginseng contains many physiologically important constituents that include saponins, oils and phytosterol, carbohydrates and sugar, organic acids, nitrogenous substances, aminoacids and peptides, vitamins and minerals (iron, copper and zinc), and several enzymes (Attele et al., 1999). Of the various compounds isolated from ginseng roots, the ginsenosides are known to have multiple pharmacological activities (Baek et al., 2006 and Wang et al., 2007).

Recent researchs indicates that ginseng has powerful antioxidant properties that may explain its initiating, anti-inflammatory, anti-cancer and antineoplastic effects (Kitts and $\mathrm{Hu}, 2000$ ). Treatment with ginseng extract and dietary supplementation of ginseng have shown a variety of protective effects against oxidative damage in vitro and in vivo, ranging from isolated LDL oxidation and ischemic neuron dysfunction, to heart reperfusion injury and physical exercise (Voces et al., 1999). Furthermore, ginseng treatment reportedly increases longevity in rodents and used as a therapeutic agent for various diseases including hyperlipidemia, atherosclerosis and hypertension (Jiang et al., 2000).

Although a primary function of ginsenosides appears to be related to its free radical scavenging activity, some ginsenoside fractions have been shown to induce antioxidant enzyme cytosolic superoxide dismutase via enhanced nuclear protein binding to its promoter (Chang et al., 1999). Also, results of clinical research studies demonstrate that panax ginseng may improve psychologic function (Wesnes $\boldsymbol{e t}$ al., 2000), immune function (Scaglione $\boldsymbol{e t}$ al., 1990 and 2001), and conditions associated with diabetes (Sotaniemi et al., 1995).

\section{Material and Methods}

\section{Experimental animals}

Male adult Wister albino rats weighing 150$200 \mathrm{~g}$ purchased from the Egyptian Organization for Biological products and Vaccines were used as experimental animals. Animals were maintained under standard conditions of ventilation, temperature and humidity. The rats were fed on standard pellets, containing all nutritive elements, and water intake was ad libitum

\section{Irradiation facility}

The irradiation facility was provided by the NCRRT, Nasr City, Cairo, Egypt. The source was ${ }^{137}$ Cesium, Gamma cell-40 manufactured by the Atomic Energy of Canada Limited. The animals were received intermittent radiation dose level of $2 \mathrm{~Gy}$ increments delivered twice a week up to a cumulative dose of $8 \mathrm{~Gy}$, at a dose rate of $1.4 \mathrm{~Gy} / \mathrm{min}$.

\section{Wheat germ oil and Panax ginseng treatment}

Wheat germ oil was supplied as a soft gel, was obtained from Arab Co. for PHARM. and Medicinal plants (MEPACO) Egypt. Wheat germ oil was dissolved in sesame oil just before the application to the rats. It was given to animals by gavage using stomach tube at a concentration of $81 \mathrm{mg} / \mathrm{kg}$ body weight (Said and Azab, 2006).

Panax ginseng was purchased from EIPICO, Egypt. It was dissolved in saline and intraperitaneally administrated to rats at a dose of $100 \mathrm{mg} / \mathrm{kg}$ body weight (Song et al., 
2003).

\section{Experimental design}

Animals were divided into 4 groups each of 8 rats: 1- Control (untreated) 2- Treated received combined mixture of wheat germ oil and panax ginseng 3- Irradiated: The animals were exposed to the fractionated dose of $\square$-irradiation ( 8 Gy) for 2 weeks. 4Treated-irradiated: animals of this group were supplied with both mixtures wheat germ oil and panax ginseng for 10 successive days before whole body exposure to gamma-radiation and supplementation was extended during the period of radiation exposure.

Sex animals from each group were randomly sacrificed by cervical dislocation $7^{\text {th }}$ and $10^{\text {th }}$ days post irradiation. Blood samples were obtained by heart puncture from ether anaesthetized rats. Serum samples were prepared by centrifugation at 3000 r.p.m. and liver samples were collected and prepared following normal laboratory procedures, for the measurement of the biochemical parameters. Liver tissues were homogenized in saline by the percentage of 1:9 tissue to saline respectively.

\section{Biochemical analysis}

The following parameters were measured: In serum, ASAT and ALAT activities was measured as described by Reitman and Frankel (1957), Ammonia and butyryl cholinesterase were determined according to the methods of (Wolheim, 1984 and Knedel and Bottger, 1967) respectively. Total protein, albumin and globulin were performed according to methods of Flask and Woollen (1984), Doumas et al., (1971) and Oser (1971), respectively. Creatinine and urea were estimated according to the procedure of Bartles and Bohmer, (1972) and Fawcett and Soctt, (1960), respectively. The content of total cholesterol (TC), triacylglycerols(TG), high-density lipoproteins (HDL) and low- density lipoproteins (LDL) were assayed according to the methods of Richmond, (1973), Fossati and Prencipe (1982), LopazVirella et al., (1977), and Marshall (1992), respectively.

\section{Statistical analysis}

Analysis of data was performed using analysis of variance (ANOVA) followed by Duncan's test. (SAS "Statistical Analysis System", 1988).

\section{Results}

No signs of toxicity were reported due to administration of combined treatment of wheat germ oil and panax ginseng with animals. Also, no death was registered during the period of treatment.

The results obtained in the present study showed that the combined administration of wheat germ oil and ginseng to rats for 24 consecutive days induced insignificant changes in serum ASAT and ALAT activity, ammonia, butyryl cholinesterase, total protein, albumin, globulin, creatinine, urea and lipid profile (Tables 1-5).

Whole body exposure of rats to gammaradiation (delivered as 2 Gy 2 times a week for 2 weeks) induced a significant increase in serum ASAT and ALAT activity, ammonia, butyryl cholinesterase, creatinine, urea, TC, TG, LDL-C accompanied with a significant decreases in levels of total protein, albumin, globulin and HDL-C, $7^{\text {th }}$ and $10^{\text {th }}$ days after the last irradiation dose as compared to control levels (Tables 1-5). Animals receiving wheat germ oil and panax ginseng for 10 consecutive days before irradiation and daily during the period of radiation exposure $\left(7^{\text {th }}\right.$ and $10^{\text {th }}$ days) showed a significant decrease of serum ASAT and ALAT activity, ammonia, butyryl cholinesterase, creatinine, urea, TC, TG, LDL-C levels compared to those of irradiated rats (Tables 1,2,4 and 5). These changes were associated with a significant increase in the levels of total protein, albumin, globulin and HDL-Concentration, as compared to irradiated rats (Table 3).

The concentration of lipid peroxides (TBARS) showed a significant increase 
Prophylactic role....

levels as compared to control rats during the $7^{\text {th }}$ and $10^{\text {th }}$ days of experimental intervals in the examined liver tissue in addition to blood plasma $(\mathrm{P} \leq 0.05)$, Table (6).
TBARS concentrations in liver and plasma were significantly decreased in treated group as compared to irradiated rats $(\mathrm{P} \leq 0.05)$, Table (6).

Table 1 Effect of combined administration of wheat germ oil and panax ginseng to irradiated rats on serum activity of ASAT and ALAT

\begin{tabular}{|c|c|c|c|}
\hline $\begin{array}{l}\text { Animal } \\
\text { groups }\end{array}$ & $\begin{array}{c}\text { Time } \\
\text { intervals }\end{array}$ & $\begin{array}{c}\text { ASAT } \\
(\mathbf{U} / \mathbf{L})\end{array}$ & $\begin{array}{r}\text { ALAT } \\
\text { (U/L) }\end{array}$ \\
\hline \multirow[t]{2}{*}{ Control } & $7^{\text {th }}$ day & $85.8 \pm 2.2$ & $22.25 \pm 2.3$ \\
\hline & $10^{\text {th }}$ day & $83.75 \pm 5.4$ & $22.33 \pm 3.1$ \\
\hline \multirow{2}{*}{$\begin{array}{l}\text { Wheat germ } \\
\text { oil +Ginseng }\end{array}$} & $7^{\text {th }}$ day & $83.33 \pm 4.4^{\mathrm{cd}}$ & $22 \pm 1.8^{\mathrm{cd}}$ \\
\hline & $10^{\text {th }}$ day & $86 \pm 5.7^{\mathrm{cd}}$ & $24.33 \pm 1.9^{\mathrm{c}}$ \\
\hline \multirow[t]{2}{*}{ Irradiation } & $7^{\text {th }}$ day & $117 \pm 3.3^{\mathrm{a}}$ & $36.33 \pm 3^{\mathrm{a}}$ \\
\hline & $10^{\text {th }}$ day & $119 \pm 4.2^{\mathrm{a}}$ & $27.25 \pm 1.5^{\mathrm{a}}$ \\
\hline \multirow{2}{*}{$\begin{array}{c}\text { Wheat germ } \\
\text { oil } \\
\text { +Ginseng+ } \\
\text { Irradiation }\end{array}$} & $7^{\text {th }}$ day & $91 \pm 1.4^{\mathrm{cd}}$ & $25.5 \pm 1.8^{c}$ \\
\hline & $10^{\text {th }}$ day & $87.14 \pm 3^{\mathrm{cd}}$ & $26.67 \pm 1.9^{c}$ \\
\hline
\end{tabular}

Data are mean of 6 animals \pm S.E and are considered significant at $\mathrm{p}<0.05$.

a: Significant difference from control.

b: Significant difference from corresponding wheat germ oil + ginseng treated group.

c: Significant difference from irradiation 7 day.

d: Significant difference from irradiation 10 days 
Table 2 Effect of combined administration of wheat germ oil and panax ginseng to irradiated rats on serum level of ammonia and butyryl cholinesterase

\begin{tabular}{|c|c|c|c|}
\hline Animal groups & $\begin{array}{c}\text { Time } \\
\text { intervals }\end{array}$ & $\begin{array}{l}\text { Ammonia } \\
\text { (ug/dl) }\end{array}$ & $\begin{array}{c}\text { Butyryl cholinesterase } \\
\text { (U/L) }\end{array}$ \\
\hline \multirow[t]{2}{*}{ Control } & $7^{\text {th }}$ day & $170.6 \pm 8.8$ & $540.86 \pm 16.8$ \\
\hline & $10^{\text {th }}$ day & $175.61 \pm 10.2$ & $558.03 \pm 10.4$ \\
\hline \multirow{2}{*}{$\begin{array}{l}\text { Wheat germ oil } \\
\text { +Ginseng }\end{array}$} & $7^{\text {th }}$ day & $175.04 \pm 5.9^{\mathrm{cd}}$ & $557.2 \pm 27.7^{\mathrm{cd}}$ \\
\hline & $10^{\text {th }}$ day & $188.66 \pm 7.5^{\mathrm{cd}}$ & $569.05 \pm 28.6^{\mathrm{cd}}$ \\
\hline \multirow[t]{2}{*}{ Irradiation } & $7^{\text {th }}$ day & $238 \pm 7^{\mathrm{a}}$ & $770.24 \pm 42.4^{\mathrm{a}}$ \\
\hline & $10^{\text {th }}$ day & $246.54 \pm 5.3^{\mathrm{a}}$ & $788.97 \pm 45.4^{\mathrm{a}}$ \\
\hline \multirow{2}{*}{$\begin{array}{l}\text { Wheat germ oil } \\
\text { +Ginseng+ } \\
\text { Irradiation }\end{array}$} & $7^{\text {th }}$ day & $218.88 \pm 4^{\text {abc d }}$ & $700.05 \pm 27.5^{\mathrm{ab}}$ \\
\hline & $10^{\text {th }}$ day & $189.46 \pm 6.6^{\mathrm{cd}}$ & $567 \pm 10.8^{\mathrm{cd}}$ \\
\hline
\end{tabular}

Legends as in Table1

Table 3 Effect of combined administration of wheat germ oil and panax ginseng to irradiated rats on serum levels of total protein, albumin, globulin and $\mathrm{A} / \mathrm{G}$ ratio

\begin{tabular}{|c|c|c|c|c|c|}
\hline $\begin{array}{l}\text { Animals } \\
\text { groups }\end{array}$ & $\begin{array}{c}\text { Time } \\
\text { intervals }\end{array}$ & $\begin{array}{l}\text { Total protein } \\
\text { (g/dl) }\end{array}$ & $\begin{array}{l}\text { Albumin } \\
\text { (g/dI) }\end{array}$ & $\begin{array}{l}\text { Globulin } \\
\text { (g/dI) }\end{array}$ & $\begin{array}{l}\text { A/G } \\
\text { Ratio }\end{array}$ \\
\hline \multirow[t]{2}{*}{ Control } & $7^{\text {th }}$ day & $6.6 \pm 0.2$ & $4 \pm 0.05$ & $2.67 \pm 0.28$ & $1.57 \pm 0.2$ \\
\hline & $10^{\text {th }}$ day & $6.5 \pm 0.2$ & $3.91 \pm 0.09$ & $2.46 \pm 0.24$ & $1.71 \pm 0.2$ \\
\hline \multirow{2}{*}{$\begin{array}{l}\text { Wheat germ } \\
\text { oil +Ginseng }\end{array}$} & $7^{\text {th }}$ day & $6.7 \pm 0.49^{\mathrm{cd}}$ & $4.06 \pm 0.03^{\mathrm{cd}}$ & $2.90 \pm 0.63^{c}$ & $1.57 \pm 0.3$ \\
\hline & $10^{\text {th }}$ day & $6.4 \pm 0.2^{\mathrm{cd}}$ & $3.93 \pm 0.05^{\mathrm{cd}}$ & $2.43 \pm 0.15^{\mathrm{c}}$ & $1.64 \pm 0.1$ \\
\hline \multirow[t]{2}{*}{ Irradiation } & $7^{\text {th }}$ day & $5.4 \pm 0.4^{\mathrm{a}}$ & $2.69 \pm 0.05^{\mathrm{a}}$ & $1.82 \pm 0.0^{\mathrm{a}}$ & $1.43 \pm 0.3$ \\
\hline & $10^{\text {th }}$ day & $4.9 \pm 0.05^{\mathrm{a}}$ & $2.44 \pm 0.1^{\mathrm{a}}$ & $2.17 \pm 0.07^{\mathrm{a}}$ & $1.04 \pm 0.02^{\mathrm{a}}$ \\
\hline \multirow{2}{*}{$\begin{array}{c}\text { Wheat germ } \\
\quad \text { oil } \\
\text { +Ginseng+ } \\
\text { Irradiation }\end{array}$} & $7^{\text {th }}$ day & $7.4 \pm 0.2^{\mathrm{acd}}$ & $4.04 \pm 0.2^{\mathrm{cd}}$ & $2.68 \pm 0.12^{\mathrm{c}}$ & $1.3 \pm 0.1$ \\
\hline & $10^{\text {th }}$ day & $6.5 \pm 0.3^{c d}$ & $4.05 \pm 0.04^{\mathrm{cd}}$ & $2.46 \pm 0.05^{\mathrm{c}}$ & $1.74 \pm 0.01^{\mathrm{bcd}}$ \\
\hline
\end{tabular}

Legends as in Table1. 
Table 4 Effect of combined administration of wheat germ oil and panax ginseng to irradiated rats on the levels of creatinine and urea

\begin{tabular}{|c|c|c|c|}
\hline $\begin{array}{c}\text { Animals } \\
\text { groups }\end{array}$ & $\begin{array}{c}\text { Time } \\
\text { intervals }\end{array}$ & $\begin{array}{c}\text { Creatinine } \\
(\mathbf{m g} / \mathbf{d L})\end{array}$ & $\begin{array}{c}\text { Urea } \\
(\mathbf{m g} / \mathbf{d L})\end{array}$ \\
\hline \multirow{2}{*}{ Control } & $7^{\text {th }}$ day & $0.66 \pm 0.03$ & $52.4 \pm 2.1$ \\
\cline { 2 - 4 } & $10^{\text {th }}$ day & $0.71 \pm 0.04$ & $51.75 \pm 2.6$ \\
\hline $\begin{array}{c}\text { Wheat germ } \\
\text { oil +Ginseng }\end{array}$ & $7^{\text {th }}$ day & $0.67 \pm 0.01^{\text {c d }}$ & $55 \pm 2.9^{\mathrm{d}}$ \\
\cline { 2 - 4 } & $10^{\text {th }}$ day & $0.72 \pm 0.03^{\mathrm{d}}$ & $52.67 \pm 4.5^{\mathrm{d}}$ \\
\hline \multirow{2}{*}{$\begin{array}{c}\text { Irradiation } \\
\text { the }\end{array}$} & $7^{\text {th }}$ day & $0.76 \pm 0.03^{\mathrm{a}}$ & $59.5 \pm 1.8^{\mathrm{a}}$ \\
\cline { 2 - 4 } & $10^{\text {th }}$ day & $0.92 \pm 0.1^{\mathrm{a}}$ & $66.5 \pm 1.1^{\mathrm{a}}$ \\
\hline $\begin{array}{c}\text { Wheat germ } \\
\text { +Ginseng+ } \\
\text { Irradiation }\end{array}$ & $7^{\text {th }}$ day & $0.69 \pm 0.06^{\mathrm{d}}$ & $58.5 \pm 4.6$ \\
\cline { 2 - 4 } & $10^{\text {th }}$ day & $0.66 \pm 0.03^{\mathrm{cd}}$ & $54 \pm 1.4^{\mathrm{d}}$ \\
\hline
\end{tabular}

Legends as in Table1.

Table 5 Effect of combined administration of wheat germ oil and panax ginseng to irradiated rats on serum level of TC, TG, HDL-C, LDL-C and HDL/LDL ratio.

\begin{tabular}{|c|c|c|c|c|c|c|}
\hline $\begin{array}{c}\text { Animals } \\
\text { groups }\end{array}$ & $\begin{array}{c}\text { Time } \\
\text { interval } \\
\mathrm{s} \\
\end{array}$ & $\begin{array}{c}\text { TC } \\
\mathrm{mg} / \mathrm{dl}\end{array}$ & $\begin{array}{c}\text { TG } \\
\mathrm{mg} / \mathrm{dl}\end{array}$ & $\begin{array}{l}\text { HDL-C } \\
\text { mg/dl }\end{array}$ & $\begin{array}{c}\text { LDL-C } \\
\text { mg/dl }\end{array}$ & $\begin{array}{c}\text { HDL/ } \\
\text { LDL Ratio }\end{array}$ \\
\hline \multirow[t]{2}{*}{ Control } & $7^{\text {th }}$ day & $84.09 \pm 2.1$ & $75.1 \pm 3.8$ & $73 \pm 7.1$ & $50.91 \pm 2.5$ & $1.33 \pm 0.1$ \\
\hline & $10^{\text {th }}$ day & $82.22 \pm 2.4$ & $77.43 \pm 4.9$ & $71 \pm 5$ & $51 \pm 3.3$ & $1.41 \pm 0.1$ \\
\hline \multirow{2}{*}{$\begin{array}{l}\text { Wheat germ } \\
\text { oil +Ginseng }\end{array}$} & $7^{\text {th }}$ day & $82.22 \pm 3.6^{c d}$ & $70.42 \pm 2.2^{\mathrm{cd}}$ & $68 \pm 4.3^{\mathrm{cd}}$ & $51.7 \pm 3.5^{\mathrm{cd}}$ & $1,21 \pm 0.1$ \\
\hline & $10^{\text {th }}$ day & $80 \pm 4.7^{c d}$ & $74.86 \pm 2.4^{\text {cd }}$ & $68.7 \pm 2.4^{\mathrm{cd}}$ & $50.2 \pm 2.5^{\mathrm{cd}}$ & $1.48 \pm 0.2$ \\
\hline \multirow[t]{2}{*}{ Irradiation } & $7^{\text {th }}$ day & $99.85 \pm 4.6^{\mathrm{a}}$ & $103.24 \pm 4.3^{\mathrm{a}}$ & $51 \pm 3.5^{\mathrm{a}}$ & $90.43 \pm 8.8^{\mathrm{a}}$ & $1.19 \pm 0.1$ \\
\hline & $10^{\text {th }}$ day & $96.36 \pm 2.6^{\mathrm{a}}$ & $99.86 \pm 5.0^{\mathrm{a}}$ & $53 \pm 3.1^{\mathrm{a}}$ & $75.5 \pm 8.8^{\mathrm{a}}$ & $0.77 \pm 0.04^{\mathrm{a}}$ \\
\hline \multirow{2}{*}{$\begin{array}{c}\text { Wheat germ } \\
\text { oil } \\
\text { +Ginseng+ } \\
\text { Irradiation } \\
\end{array}$} & $7^{\text {th }}$ day & $90.44 \pm 3.5$ & $76.86 \pm 2.6^{\mathrm{cd}}$ & $69.5 \pm 6^{\mathrm{cd}}$ & $53.4 \pm 1.9^{\text {cd }}$ & $1.32 \pm 0.2$ \\
\hline & $10^{\text {th }}$ day & $87.81 \pm 4^{\mathrm{cd}}$ & $84 \pm 7.7^{c}$ & $70.33 \pm 4.2^{\mathrm{cd}}$ & $51.32 \pm 4.9^{\text {cd }}$ & $1.37 \pm 0.1$ \\
\hline
\end{tabular}

Legends as in Table1. 
Table 6 Effect of combined administration of wheat germ oil and panax ginseng to irradiated rats on serum and liver level of TBARS

\begin{tabular}{|c|c|c|c|}
\hline $\begin{array}{l}\text { Animals } \\
\text { groups }\end{array}$ & $\begin{array}{c}\text { Time } \\
\text { intervals }\end{array}$ & Liver (n mol/g fresh tissue) & Plasma $(\mathrm{n} \mathrm{mol} / \mathrm{ml})$ \\
\hline \multirow[t]{2}{*}{ Control } & $7^{\text {th }}$ day & $239 \pm 12$ & $11.20 \pm 0.80$ \\
\hline & $10^{\text {th }}$ day & $245 \pm 11$ & $11.00 \pm 0.77$ \\
\hline \multirow{2}{*}{$\begin{array}{l}\text { Wheat germ } \\
\text { oil +Ginseng }\end{array}$} & $7^{\text {th }}$ day & $237 \pm 13$ & $10.90 \pm 0.70^{c d}$ \\
\hline & $10^{\text {th }}$ day & $240 \pm 14$ & $10.80 \pm 0.72^{\mathrm{cd}}$ \\
\hline \multirow[t]{2}{*}{ Irradiation } & $7^{\text {th }}$ day & $388 \pm 18^{\mathrm{a}}$ & $21.0 \pm 1.7^{\mathrm{a}}$ \\
\hline & $10^{\text {th }}$ day & $401 \pm 16^{\mathrm{a}}$ & $22.7 \pm 2.0^{\mathrm{a}}$ \\
\hline \multirow{2}{*}{$\begin{array}{c}\text { Wheat germ } \\
\quad \text { oil } \\
\text { +Ginseng+ } \\
\text { Irradiation }\end{array}$} & $7^{\text {th }}$ day & $300 \pm 17^{\text {acd }}$ & $14.0 \pm 1.0^{\mathrm{acd}}$ \\
\hline & $10^{\text {th }}$ day & $310 \pm 16^{\text {acd }}$ & $15.0 \pm 1.47^{\mathrm{acd}}$ \\
\hline
\end{tabular}

Legends as in Table1.

\section{Discussion}

Herbals, as botanical medical treatments, have generated a deal of public controversy in recent years. The constituents of ginseng that have been found are saponin (ginsenosides) as its major component, polysaccharide, polyacetylene, flavonoids, daucosterin, mucilaginous substances, amino acids, bitter substances, choline, pectin, fatty oil and ethereal oil (Shin et al., 2000).

The data in the present study revealed that a significant elevation in serum ASAT and ALAT activities, ammonia and butyryl cholinesterase was recorded post exposure of rats to gamma-radiation at all time intervals, which reflects detectable changes in liver function. This significant increase of these enzymes level may be attributed to the changes in tissue permeability due to irradiation that could enhance the release of the transaminases from their subcellular sites of production to extra cellular proceeds consequently to the blood circulation. The current investigation combined administration to irradiated rats effect of wheat germ oil and ginseng was done in view of possible minimizing the toxicity of ionizing radiation. The present work declared the significant elevation in liver enzymes as a result of $\square$-radiation exposure was reduced by the treatment of irradiated rats with germ oil and ginseng before and during radiation exposure Ammar (2009). In the present study, treatment of irradiated rats with both wheat germ oil and ginseng revealed non significant changes in the investigated parameters indicating its safe use. It seems that the present results agree with those of Sisodia et al., (2007) and Kunwar et al., (2010) who reported that ionizing radiation induce augmentation in the levels of serum ASAT and ALAT that were significantly ameliorated by pretreatment with natural radio-protector.

One of the factors that play a central role in many pathways of radiation-induced damage is oxidative stress. Excessive production of oxygen radicals leads to altered enzyme activity, decreased DNA repair, and impaired utilization of oxygen, lipid peroxidation and protein oxidation. (Kurose et al., 1996). 
Ammonia is present in all living organisms as a product of degradation of proteins and other nitrogenous compounds. However, at higher levels, ammonia is toxic, leading to functional disturbances in the central nervous system that could lead to coma and death (Subash and Subramanian, 2008).

The irradiation of rats induced a decrease in serum total proteins, albumin, globulin and $\mathrm{A} / \mathrm{G}$ ratio in response to ionizing radiation. This event may be attributed to impaired hepatic proteins synthesis due to damage of liver cells (Srinivasan et al., 1985), loss from circulation, by leakage to the urine and/or enhanced proteins degradation (Mahdy, 1991). Irradiation seems likely to alter immune response of animals producing immune gamma-globulin (Roushdy et al., 1984). Combined administration of wheat germ oil and ginseng before irradiation and daily during the period of radiation exposure significantly reduced the severity of changes which might be attributed to the antioxidant nature of vitamin $\mathrm{E}$ in wheat germ oil and ginseng, and its role in the maintenance of cell membrane structure (Bansal et al., 2005).

Gamma irradiation of animals caused a significant increase in the level of serum creatinine and urea. Increase in serum urea was due to increase in glutamate dehydrogenase enzyme as a result of irradiation and this may increase carbamoyl phosphate synthetase activity leading to increase in urea concentration, Ramadan $\boldsymbol{e t}$ al., (2001). The impaired detoxification fuction of the liver by irradiation could also contribute in the increase of urea in the blood (Robbins et al., 2001) or deteriorating renal performance (Geraci et al., 1990). Serum creatinine elevation by irradiation was attributed to the interaction of creatinine with their sites of biosynthesis (El-Kashef and Saada 1988). Combined administration of wheat germ oil and ginseng before and daily within the period of irradiation significantly reduced the radiation-induced oxidative damage in the kidney. The results are consistent with those of Alessandri et al., (2006) who reported that combined administration of wheat germ oil and ginseng decrease oxidative stress.

Wheat germ oil serves to lower marker of lipid peroxidation and stimulates antioxidant capacity of erythrocytes in radiated rats. Thus, the susceptibility of blood cells to peroxidation is decreased so the blood picture is improved. Wheat germ oil contains some B complex vitamins (B6, B12 and folic acid) that are essential in the formation of red blood cells (Vicky et al., 2004). It was claimed to be antiinflammatory and described as a suitable natural antioxidant due to its high content of vitamin E (Paranich et al., 2000). The oil was reported, also, to be a valuable source of essential fatty acids, including linoleic acid and linolenic acid whose insufficiency was observed to cause tiredness, dry skin, immune insufficiency, anorexia, indigestion and cardiovascular disorders (Mohamed $\boldsymbol{e t}$ al., 2005).

The present results showed an increase in serum total cholesterol, triglycerides and LDL-C with concomitant decrease in HDL$\mathrm{C}$ level of irradiated. This may be explained by a reduction in the activity of lipoprotein lipase or hepatic lipase leading to elevated triglycerols level or other inflammatory products released following radiation exposure with modification of triglycerols metabolism indirectly (Sedlakova et al., 1986). The hypercholesterolemia induced by irradiation of rats can be attributed to the increase in activation of $\beta$-hydroxy-3methyl-glutaryl COA (HMG-COA) reductase which is the key regulatory enzyme of reaction process of cholesterol biosynthesis resulting in reduction of lipoprotein catabolism (Sedlakova et al., 1988). The combined administration of wheat germ oil and ginseng to rats before irradiation and daily during the period of radiation exposure lowered TG level may be due to an increase in membrane permeability and fluidity causing decrease triglycerides and cholesterol levels, Yousri et al., (1991). Several studies have demonstrated that monounsaturated fatty acid reduce serum TG level (Jenkins et al., 1999), in addition, wheat germ oil (WGO) has a number of other nutritional and health benefits factors 
like high content of vitamin $\mathrm{E}$ and phytosterol (Jonnala et al., 2005) which may be the reason of its lowering effect on triglyceride thus the reducing effect of WGO on triglyceride level was a positive finding of this study.

Said and Azab, (2006) reported that supplementation of rats with wheat germ oil $(81 \mathrm{mg} / \mathrm{kg}$ body $\mathrm{wt}$ ) for 10 successive days before and 7 successive days after whole body gamma irradiation, significantly ameliorated serum lipid profile levels and reduced the severity of changes in the activity of serum CPK and modulated the alteration in activity of LDH and its isoenzymes patterns when compared with irradiated rats. Moreover, guinea pigs receiving wheat germ oil did not develop muscular dystrophy and showed normal creatine values (Nobuko et al., 2008). Wheat germ oil is rich in vegetable oil compounds, particularly vitamin $\mathrm{E}$, octacosanol and omega-3 fatty acids (Moure et al., 2001). Furthermore, studies have shown that linoleic and linolenic acidsrich wheat germ oil decreases oxidative stress in patients with mild hypercholesterolemia (Alessandri et al., 2006).

Alessandri et al, (2006) provided an evidence that wheat germ oil is an important source of n-3 fatty acids, which may exert an antiatherosclerotic effect via inhibition of oxidative stress-mediated CD40L upregulation.

Panax ginseng C.A. Meyer is a well-known medicinal herb native to China and Korea, and has been used as a herbal remedy in eastern Asia for thousands of years. However, there is different evidence of ginseng efficacy between traditional Chinese medicine (TCM), modern pharmacological experiments and clinical trials. In TCM, ginseng is a highly valued herb and has been applied to a variety of pathological conditions and illnesses such as hypodynamia, anorexia, shortness of breath, palpitation, insomnia, impotence, hemorrhage and diabetes. Modern pharmacological experiments have proved that ginseng possesses multiple constituents (ginsenosides, polysaccharides, peptides, polyacetylenic alcohols, etc.) and actions (central nervous system effects, neuroprotective effect, immunomodulation, anticancer, etc.), ginsenosides as the active ingredients, especially, having antioxidant, anti-inflammatory, anti-apoptotic and immunostimulant properties. Recently, ginseng has been studied in a number of randomized controlled trials investigating its effect mainly on physical and psychomotor performance, cognitive function, immunomodulation, diabetes mellitus, cardiovascular risk factors, quality of life, as well as adverse effects. Equivocal results have been demonstrated for many of these indications. Because of the poor quality of most clinical trials on ginseng, reliable clinical data in humans are still lacking. Therefore, a broader understanding of medical knowledges and reasoning on ginseng is necessary (Xiang et al., 2008).

Kim and Park (2003) observed that serum TC, TG, LDL and plasma MDA levels were decreased by administration of panax ginseng extract (PGE) in humans for 8 weeks, but HDL was increased. Those results suggest that hypolipidemic effect of PGE is associated with a decrease in TC, TG, LDL and plasma MDA levels, and an increase in HDL. These findings support scientific claims that ginseng has hypolipidemic effect or antioxidant potential as the preventive or therapeutic supplementation of hyperlipidemia.

Ginseng that has been used as a medicine for at least 2,000 years currently is being cultivated throughout the world (Kennedy and Scholey, 2003). Numerous biochemical and pharmacological studies revealed that ginseng possess various biological properties as an anticancer, antioxidant, antiinflammatory, antibiotic, anti-fungal and anti-hepatotoxic agent. Anticancer and therapeutics were potent of its active components such as ginsenosides in saponins of the 46 ginseng root, while polysaccharides have been observed to have immunomodulating and antiproliferative effects in certain tumor cell lines (Kitts and Hu, 2000; Ben-Hur and Fulder, 1981; 
Song et al., 2003, Chang et al., 2002 and Lee et al., 2005). Most effects of ginseng have been attributed to its antioxidant action and strongly radioprotective through its ability to stimulate hematopoietic stem cells. Kumar et al., (2003) stated that ginseng markedly inhibits lipid peroxidation. It acts in indirect fashion to protect radical processes by inhibition of initiation of free radical processes and thus reduces the radiation damages in testes of Swiss albino mice.

According to the above stated results it could be concluded that supplementation of both wheat germ oil and ginseng to irradiated rats enhanced antioxidant activities and decreased lipid peroxidation, which may afford protection against radiation exposure hazards and oxidative stress and might preserve the integrity of tissue functions and minimize metabolic body disorders. Hence combined wheat germ oil and ginseng administration prior to radiation therapy may be useful to cancer patients to prevent normal cell da

\section{References}

Alessandri C, Pignatelli P, Loffredo L, Lenti L, Del Ben M, Carnevale R, Perrone A, Ferro D, Angelico F, Violi F. (2006): Alpha-linolenic acid-rich wheat germ oil decreases oxidative stress and CD40 ligand in patients with mild hypercholesterolemia. Arterioscler thromb Vas Biol., 26(11):2577-2588.

Ammar AA. (2009): Evaluation of the protective role of wheat germ oil in irradiated rats. Isotope and Rad. Res., 41: 911-920.

Attele AS, Wuja JA, Yuan CS. (1999): Ginseng pharmacology: Multiple constituents and multiple actions. Biochem. Pharmacol., 58: 1685-1693.

Baek SH, Piao XL, Lee UJ, Kim HY, Park JH. (2006): Reduction of cisplatin- induced nephrotoxicity by ginsenosides isolated from processed ginseng in cultured renal tubular cells. Biol. Pharma. Bull., 29 (10): 2051-2055.

Bansal AK Bansal M, Soni G, Bhatnagar D. (2005): Protective role of vitamin $E$ pretreatment on $\mathrm{N}$ - nitrosodiethylamine induced oxidative stress in rat liver. Chem. Biol. Interact., 156 (2-3): 101-111.

Barttes H, Böhmer M, Heierli C. (1972): Serum creatinine determination without protein precipitation. Clin. Chem. Acta., 37: 193-7

Ben-Hur E and Fulder S. (1981): Effect of Panax ginseng saponins and Eleutherococcus senticosus on survival of cultured mammalian cells after ionizing radiation. Am J Chin Med. Spring, 9 (1): 48-56.

Chang M S, Lee SG, Rho HM. (1999): Transcriptional activities of $\mathrm{Cu} / \mathrm{Zn}$ superoxide dismutase and catalase genes by panaxadiol ginsenosides extracted from panax ginseng. Phytother. Res., 13 (8): 641-644.

Chang TK, Chen J, Benetton SA. (2002): In vitro effect of standardized ginseng extracts and individual ginsenosides on the catalytic activity of human CYP1A1, CYP1A2, and CYP1B1. Drug Metab Dispos., 30(4):378-84.

Doumas BT, Watson WA, Biggs HG. (1971): Albumin standards and the measurement of serum albumin with bromcresol green. Clin Chim Acta., 31(1):87-96.

El-Kashef HS and Saada HN. (1988): Changes in the level of urea, creatinine in the liver and serum of irradiated rats. Isotpe and Rad. Res., 20: 43-60.

El-Masry FS and Saad TM. (2005): Role of selenium and vitamin $\mathrm{E}$ in modification of radiation disorders in male albino rats: Isotope and Rad. Res., 37: 1261-1273.

Fawcett JK and Soctt JE. (1960): A rapid and precise method for the determination of urea. $\mathrm{J}$ Clin Pathol., 13:156-9.

Flack CP and Woollen JW. (1984): Prevention of interference by dextran with biuret-type assay of serum proteins. Clin Chem., 30(4):559-61.

Fossati $P$ and Prencipe L. (1982): Serum triglycerides determined calorimetrically with an enzyme that produces hydrogen peroxide. Clin Chem., 28(10):2077-80.

Geraci JP, Jackson KL, Mariano MS, Michieli BM. (1990): Kidney and lung injury in irradiated rats protected from acute death by partial-body shielding. Rad. Res., 112: 95-115.

Irmak S and Dunford NT. (2005): Policosanol contents and compositions of wheat varieties. J. Agric Food Chem., 531(4): 5583-5586.

Jagetia GC. (2007): Radioprotective potential of plants and herbs against the effects of ionizing radiation. J. Clin. Biochem. Nutr., 40: 74-81.

Jenkins DJA, Kendall CWC, Vuksan V, Augustin LSA, Mehling CRD, Parker TRD, Vidgen E, Lee B, Fauldner D, Seyler H, Josse R, Leiter LA, Connelly PW, Fuigoni V. (1999): Effect of wheat bran on serum lipids: influence of particle size and wheat protein. J. Am. College Nutr., 18:159-165.

Jensen MK, Koh-Banerjee P, Hu FB, Franz 
M, Sampson L, Grønbaek M, Rimm EB. (2004): Intakes of whole grains, bran, and germ and the risk of coronary heart disease in men. Am J Clin Nutr., 80 (6):1492-9.

Jiang F, DeSilva S, Turnbull J. (2000): Beneficial effect of ginseng root in SOD-1 (G93A) transgenic mice. Neurol Sci., 180(12):52-4.

Jonnala RS, Dunford NT, Irmak S. (2005): Policosanol, tocopherol and phytosterol composition of wheat extract. IFT Annual Meeting, JULY 15-20, New Orleans Louisiana, 54 G-1.

Kennedy DO and Scholey AB. (2003): Ginseng: potential for the enhancement of cognitive performance and mood. Pharmacol Biochem Behav., 75(3): 687-700.

Kim SH and Park KS. (2003): Effects of Panax ginseng extract on lipid metabolism in humans. Pharmacological Research, 48: 511-513

Kitts D and Hu C. (2000): Efficacy and safety of ginseng. Public Health Nutr., 3(4A):473-85.

Knedel M and Böttger R. (1967): A kinetic method for determination of the activity of pseudocholinesterase (acylcholine acylhydrolase 3.1.1.8.). Klin Wochenschr., 15; 45(6):325-7.

Kumar M, Sharma M K, Saxena P S, Kumar A. (2003): Radioprotective Effect of Panax ginseng on the Phosphatases and Lipid Peroxidation Level in Testes of Swiss Albino Mice. Biol. Pharm. Bull., 26(3): 308-312

Kunwar A, Bansal P, Kumar SJ, Bag PP, Paaul P, Reddy ND, Kumbhare LB, Jain VK, Chaubey RC, Unnikrishnan MK, Priyadarsini

KI. (2010): In vivo radioprotection studies of 3,3-diselenodipropionic acid, a selenocystine derivative. Free Radical Biology \& Medicine, 48: 399-410.

Kurose I, Argenbright LW, Wolf R, Granger DN. (1996): Oxidative stress during plateletactivating factor-induced microvascular dysfunction. Microcirculation., 3(4):401-10.

Lee TK, Johnke RM, Allison RR, O'Brien KF, Dobbs LJ Jr. (2005): Radioprotective potential of ginseng. Mutagenesis., 20(4):237-43. Lopes-Virella MF, Stone PG, Colwell JA. (1977): Serum high density lipoprotein in diabetic patients. Diabetologia., 13(4):285-91.

Lui R.H. (2007): Whole grain phytochemicals and health. J. Cereal Sci., 46: 207-219.

Mahdy AM. (1991): Vitamin E as a chemical radio-protector controlling the radiation induced changes in the levels of protein and urea in the serum of irradiated rats. Isotope and Rad. Res., 32(2): 117-128.
Marshall WJ. (1992): Clinical Chemistry, $2^{\text {nd }}$ ed. Gower Medical Publlishing, U.K. pp. 222236.

Mohamed D, Ismael A, Ibrahim A. (2005): Studying the anti- inflammatory and biochemical effects of wheat germ oil. Dtsch. Lebensm. Rundsch., 101(2): 66.

Moure A, Cruz JM, Franco D, Domínguez JM, Sineiro J, Domínguez H, Núñez MJ, Parajó, JC. (2001): Natural antioxidants from residual sources. Food Chem., 72: 145-171.

Nobuko, S, Gladys AE, Herbeet ME. (2008): The prevention of nutritional muscular dystrophy in guinea pigs with vitamin E. J. Nutrition, 28: 547-554.

Oser BL. (1971): Hawk's Physiological Chemistry, 14th ed., (Tata McGraw, New Delhi, India), p. 441.

Paranich, V, Cherevko O, Frolova N, Paranich A. (2000): The effect of wheat germ oil on the antioxidant system of animals. Lik Sprava., 2: 40.

Ramadan LA, Shouman SA, Sayed-Ahmed MM, El-Habit OH. (2001): Modulation of radiation-induced organs toxicity by CremophorEL in experimental animals. Pharmacol. Res., 43: 185-191.

Reitman S and Frankel S. (1957): A colorimetric method for the determination of serum glutamic oxalacetic and glutamic pyruvic transaminases. Am J Clin Pathol., 28(1):56-63.

Richmond W. (1973): Preparation and properties of a cholesterol oxidase from Nocardia sp. and its application to the enzymatic assay of total cholesterol in serum. Clin Chem., 19(12):1350-6.

Robbins ME, O'Malley Y, Zhao W, Davis CS, Bonsib SM. (2001): The role of the tubulointerstitium in radiation-induced renal fibrosis. Radiat Res., 155(3):481-9.

Roushdy HM, Ibrahim H, Edrees G. (1984): Spleen homogenate for biological treatment of radiation induced disorders in the activity of certain serum and liver enzymes. Egypt. J. Rad. Sci. Applic., 1(2): 107-117.

SAS Institute (1988): SAS/STAT user's guide, 6.03 ed. SAS Institute, Cary, NC.

Said UZ and Azab KH SH. (2006): Efficacy of wheat germ oil in modulating radiation-induced heart damage in rats. Egypt. J. Rad. Sci. Applic., 19 (2): 433-451.

Scaglione F, Ferrara F, Dugnani S, Falchi M, Santoro G, Fraschini F. (1990): Immunomodulatory effects of two extracts of Panax ginseng C.A. Meyer. Drugs Exp Clin Res., $\quad$ 16(10):537-42. 
Scaglione F, Weiser K, Alessandria M. (2001): Effects of the standardized ginseng extract G 115 in patients with chronic bronchitis: a nonblinded, randomized, comparative pilot study. Clin. Drug Invest (New Zealand), 21: 41-45.

Sedlakova A, Palikova K, Ahlers I. (1986): Changes in lippoprotein lipase activity in the adipose tissue and heart on non- lethally $\mathrm{x}$ irradiated rats. Phjsiol. Bohemoslov., 35: 400.

Sedlakova A, Timko YA, Paulikova EH, Dyatelinka I. (1988): Lipid synthesis in irradiated rat thymus. Radiobiology, 28(1):80.

Shin H, Kim J, Yum T, Morgan G, Vainio H. (2000): The cancer preventive potential of panax ginseng: Areview of human and experimental evidence. Cancer Causes Control., 11: 565.

Singh DK, Li L, Porter TD. (2006): Policosanol inhibits cholesterol synthesis in hepatoma cells by activation of AMP-kinase. J. Pharmacol. Exp. Ther., 318(3): 1020.

Sisodia R, Sharma KV, Ahaskar M, Singh S. (2007): Radioprotective potential of grewia asiatica fruit extract against radiation induced hepatotoxicity in Swiss albino mice. Free Radical Biology and medicine, 43: 132.

Song JY, Han SK, Bae KG, Lim DS, Son SJ, Jung IS, Yi SY, Yun YS. (2003): Radioprotective effects of ginsan, an immunomodulator. Radiat Res., 159(6):768-74.

Sotaniemi EA, Haapakoski E, Rautio A. (1995): Ginseng therapy in non-insulindependent diabetic patients. Diabetes Care., 18(10):1373-5.

Srinivasan MN, Basu SK, Ghose A. (1985): Effect of chemical radioprotectors on serum proteins of rats exposed to gamma-irradiation. Indian J. Exp. Biol., 23: 490-500.

Subash S and Subramanian P. (2008): Effect of morin on the levels of circulatory liver markers and redox status in experimental chronic hyperammonaemic rats. Singapore Med J, 49(8): 650

Vicky U, Kristen L, Christine S. (2004): American Top 25: Supplements climbing the charts July, Natural Foods Merchandiser., XXV (7): 44.

Voces J, Alvarez AI, Vila L, Ferrando A, Cabral de Oliveira C, Prieto JG. (1999): Effects of administration of the standardized Panax ginseng extract G115 on hepatic antioxidant function after exhaustive exercise. Comp Biochem Physiol C Pharmacol Toxicol Endocrinol., 123(2):175-84.

Wang W, Zhao Y, Rayburn ER, Hill DL, Wang H, Zhang R. (2007): In vitro anticancer activity and structure-activity relationships of natural products isolated from fruits of Panax ginseng. Cancer Chemother Pharmacol., 59(5):589-601.

Wesnes KA, Ward T, McGinty A, Petrini 0. (2000): The memory enhancing effects of a Ginkgo biloba/Panax ginseng combination in healthy middle-aged volunteers. Psychopharmacology (Berl)., 152(4):353-61.

Wolheim DF. (1984): Preanalytical increase of ammonia in blood specimens from healthy subjects. Clin Chem., 30:906-8.

Xiang YZ, Shang HC, Gao XM, Zhang BL. (2008): A comparison of the ancient use of ginseng in traditional Chinese medicine with modern pharmacological experiments and clinical trials. Phytother Res., 22(7):851-8.

Yousri RM, Roushdy H, Gawwish MA. (1991): Changes in some blood lipid fractions in whole body irradiated rats as influenced by some radioprotectors. Isotopenpraxis., 27: 117-123. 


\section{الدور الوقائى للمعاملة المزدوجة بزيت جنين القمح ؤالجنسنج فى تخفيف

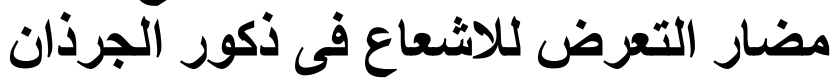

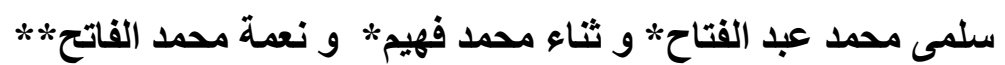

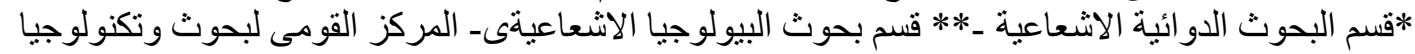

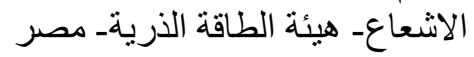

صممت الدر اسة للكثف عن التاثير ات الوقائية الممكنة للمعالجة المزدوجة بزيت جنين القمح والجنسنج

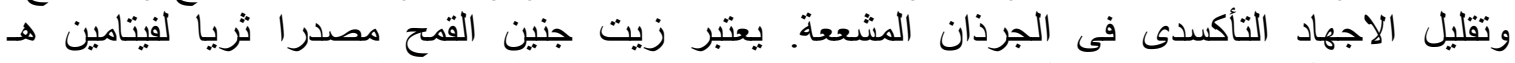

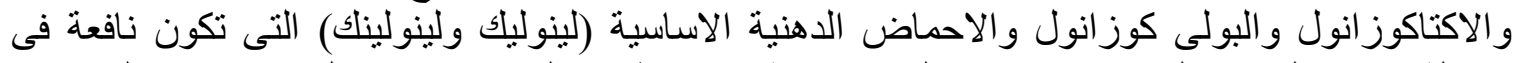

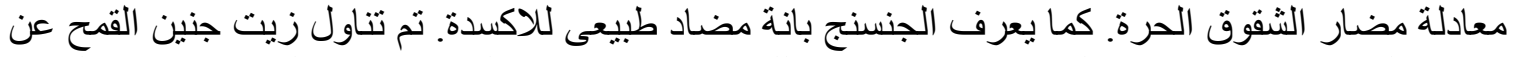

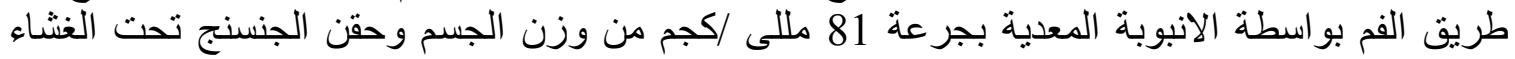

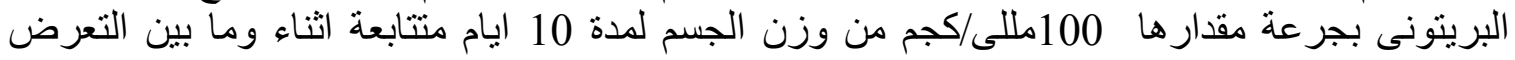

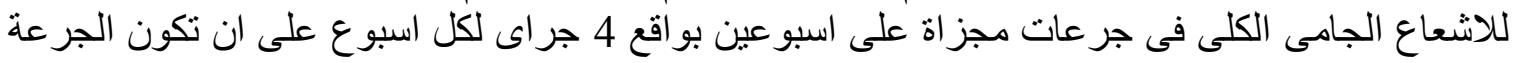

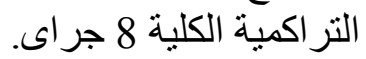

تم تعيين مستويات انزيمات الكبد( ASAT \& ALAT) و الامونيا و البيوتريل كولين استريز والبروتين

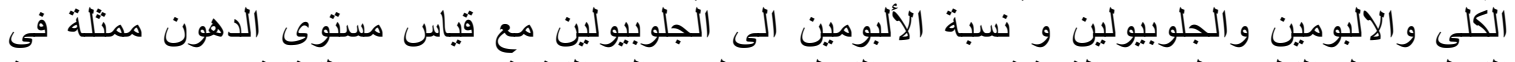

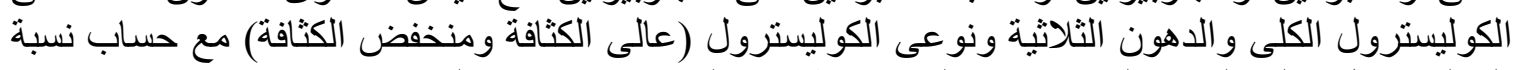

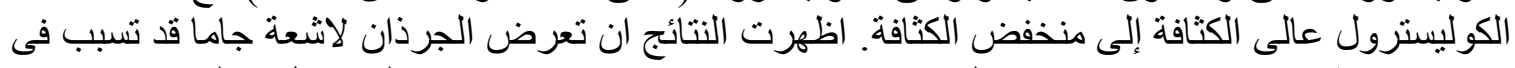

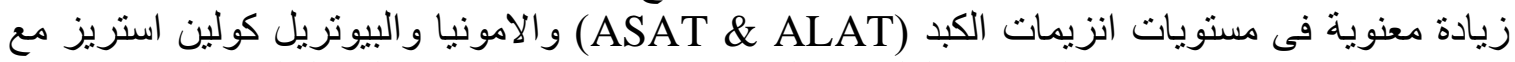

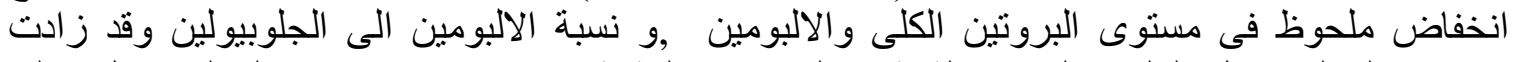

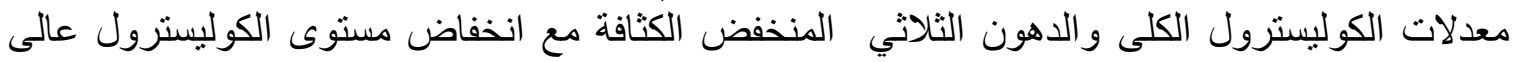

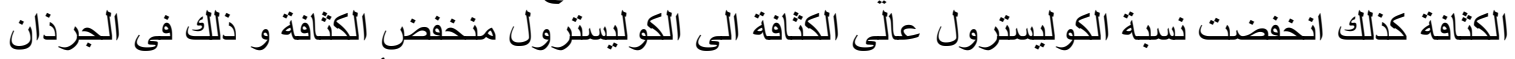

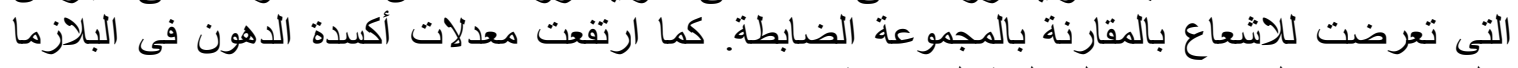

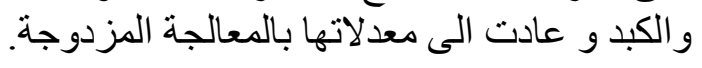

اما الجرذان التى عولجت بزيت جنين القمح والجنسنج فقد اظهرت تحسنا معنويا فى العوامل التى قيست فى الدم مقارنة بالمجمو عة المشععة.

وبناء على نتائج الدراسة فان التعرض للاشعاع يؤدى الى اختز ال كفائة انزيمات مضادات الاكسدة الدفاعية

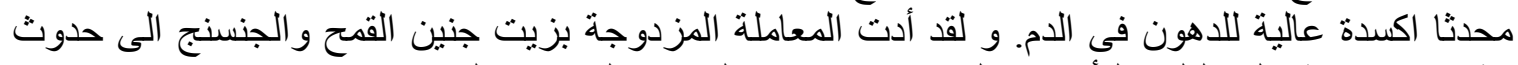
تاثير ات ايجابية على التلف التأكسدى الناتج عن تعرض الجرد الترذان للإشعاع المؤين. 